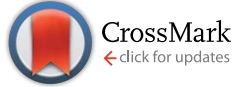

Cite this: Chem. Sci., 2015, 6, 3415

Received 7th March 2015

Accepted 31st March 2015

DOI: $10.1039 / \mathrm{c} 5 \mathrm{sc} 00835 \mathrm{~b}$

www.rsc.org/chemicalscience

\section{Pd-catalyzed asymmetric hydrogenation of fluorinated aromatic pyrazol-5-ols via capture of active tautomers $\dagger$}

\author{
Zhang-Pei Chen, ${ }^{a} \mathrm{Mu}$-Wang Chen, ${ }^{a}$ Lei Shi, ${ }^{a}$ Chang-Bin $\mathrm{Yu}^{\mathrm{a}}$ and Yong-Gui Zhou ${ }^{\mathrm{ab}}$ \\ An efficient palladium-catalyzed asymmetric hydrogenation of fluorinated aromatic pyrazol-5-ols has been \\ developed via capture of the active tautomers. A wide variety of 2,5-disubstituted and 2,4,5-trisubstituted \\ pyrazolidinones have been synthesized with up to $96 \%$ and $95 \%$ ee, respectively. The hydrogenation \\ pathway includes Brønsted acid promoted tautomerization of pyrazol-5-ols and Pd-catalyzed \\ asymmetric hydrogenation of the active tautomer.
}

Pyrazolidinones and related 1,2-diaza-3-one heterocycles are highly desirable building blocks owing to the fact that they frequently set up the core framework of numerous pharmaceutically and agrochemically active compounds. ${ }^{1}$ Particularly, aside from drug development, optically pure pyrazolidinones have also shown great advantages in synthetic methodology. ${ }^{2}$ For example, the chiral pyrazolidinones could act as efficient catalysts to promote Diels-Alder reactions, and catalyze kinetic resolution of racemic secondary alcohols. ${ }^{3}$ Over the last decades, the introduction of fluorine into molecules has received increasing attention in the fields of medicinal, agricultural, and material chemistry, primarily because the isosteric replacement of hydrogen by fluorine enhanced the lipophilicity, metabolic stability, and bioavailability of the parent compounds. ${ }^{4}$ Consequently, reliable methods toward the facile generation of optically active fluorinated pyrazolidinones would be very desirable in organic synthesis and drug research. However, the methods to chiral pyrazolidinones were still limited to transformation from chiral materials, ${ }^{5}$ classical chemical resolution ${ }^{3 a}$ or kinetic resolution involving pyrazolidinone imides, ${ }^{6}$ and the synthesis of fluorinated pyrazolidinones was rarely explored. Considering the ready availability and easy preparation of fluorinated pyrazol-5-ols, asymmetric hydrogenation of these compounds would provide atom-economical and straightforward access to optically pure pyrazolidinones (Scheme 1).

Despite much progress having been achieved in the asymmetric hydrogenation of heteroaromatics ${ }^{7}$ including

${ }^{a}$ State Key Laboratory of Catalysis, Dalian Institute of Chemical Physics, Chinese Academy of Sciences, Dalian 116023, P. R. China. E-mail: ygzhou@dicp.ac.cn

${ }^{b}$ Collaborative Innovation Centre of Chemical Science and Engineering (Tianjin), Tianjin 300071, P. R. China

$\dagger$ Electronic supplementary information (ESI) available. CCDC 1040656-1040658. For ESI and crystallographic data in CIF or other electronic format see DOI: $10.1039 / \mathrm{c} 5 \mathrm{sc} 00835 \mathrm{~b}$ quinolines, ${ }^{8}$ iso-quinolines, ${ }^{9}$ quinoxalines, ${ }^{10}$ pyridines, ${ }^{11}$ indoles, ${ }^{12}$ pyrroles, ${ }^{13}$ (benzo)furans, ${ }^{14}$ (benzo)thiophenes, ${ }^{15}$ imidazoles, ${ }^{16}$ indolizines,${ }^{17}$ pyrimidines,${ }^{18}$ and naphthyridines, ${ }^{19}$ a great number of problems still remain unsettled in this field, such as the catalytic asymmetric hydrogenation of aromatic rings containing free hydroxyl, amido or other electron-enriched functional groups and heteroarenes containing two or more adjacent heteroatoms. The intrinsic problems are apparent: (i) the inherent stability resulting from aromaticity; (ii) the strong coordination effects endowed by the heteroatoms; (iii) the difficulty of controlling the stereoselectivity; (iv) the facile cleavage of the bond between the heteroatoms. ${ }^{20}$ Therefore, the hydrogenation of this kind of electron-enriched aromatic pyrazol-5-ol with a free hydroxyl and two adjacent nitrogen-atoms is a great and significant challenge. Herein, we wish to report our initial findings on the development of a Pdcatalyzed asymmetric hydrogenation of fluorinated pyrazol-5ols with excellent enantioselectivities, yields, and diastereoselectivities.

At the outset, the readily available 1-phenyl-3-(trifluoromethyl)-1H-pyrazol-5-ol 1a, which can be synthesized from the easily accessible starting materials ethyl 4,4,4-trifluoro-3-oxobutanoate and phenylhydrazine, ${ }^{21}$ was selected as

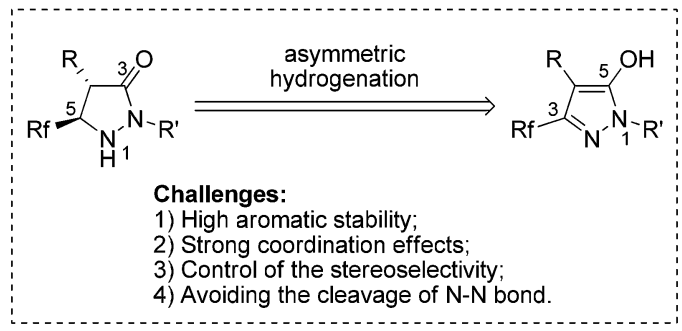

Scheme 1 Challenges in the asymmetric hydrogenation of fluorinated pyrazol-5-ols. 
the model substrate for investigation. To our disappointment, the hydrogenation failed to proceed in the presence of common $\mathrm{Rh}, \mathrm{Ru}$, and Ir catalysts (Scheme 2). This may be ascribed to the strong coordination effects and highly electron-enriched nature of fluorinated pyrazol-5-ols that impeded the hydrogenation.

In principle, these kinds of substrates exist in three tautomeric forms, i.e. the $\mathrm{OH}-($ form $\mathbf{A})$, the $\mathrm{NH}-($ form $\mathbf{B}$ ) and the $\mathrm{CH}$-isomer (form C) (Scheme 3). ${ }^{1 e, 22} \mathrm{~A}$ literature search ${ }^{23}$ and experimental data including X-ray crystal structure ${ }^{24}$ analysis demonstrated that form $\mathbf{A}$ is the most stable and dominant form. In view of the fact that the alkylation of pyrazol-5-ols would selectively lead to $O$-alkyl derivatives or $N$-alkyl derivatives as the alkylation products under specific requirements, we supposed that appropriate conditions would promote the tautomerization of the highly aromatic tautomer $\mathbf{A}$ to the more active tautomer C. Previous results have demonstrated that trifluoroacetic acid (TFA) could promote 1,4-dihydroxynaphthalene to form its stable tautomer tetralin-1,4-dione, ${ }^{25}$ and accelerate iminium-enamine isomerization to facilitate hydrogenation. ${ }^{26}$ On the basis of these analyses, we envisioned that the combination of a Pd catalyst which is excellently tolerant to $\operatorname{acid}^{27}$ and a Brønsted acid could be suitable for the asymmetric hydrogenation of fluorinated pyrazol-5-ols.

To our delight, the exposure of 1a to TFA in dichloromethane furnished the desired pyrazolidinone 2a with $91 \%$ ee and $54 \%$ conversion using $\mathrm{Pd}\left(\mathrm{OCOCF}_{3}\right)_{2} /(S)$-BINAP as the catalyst (Table 1 , entry 1). When the reaction was carried out in 2,2,2-trifluoroethanol (TFE), the reactivity and enantioselectivity dropped slightly (entry 2). Subsequently, the effects of other acids were investigated, and TFA was the most suitable choice in view of the reactivity and enantioselectivity.

Further examinations were focused on ligand screening. From the evaluation of the various commercially available chiral axial bisphosphine ligands, excellent enantioselectivity was obtained with ligand $\mathbf{L} 2$ (entry 6), providing the product in $96 \%$ ee and $81 \%$ isolated yield. When the reaction time was prolonged to 48 hours, the yield was further improved without loss of enantioselectivity (entry 10). Therefore, the optimal condition was established as: $\operatorname{Pd}\left(\mathrm{OCOCF}_{3}\right)_{2} / \mathbf{L} 2 / \mathrm{TFA}$ in dichloromethane.

With the optimal conditions in hand, exploration of the substrate scope was carried out, and the results are summarized in Table 2. Gratifyingly, a variety of 1-aryl substituted substrates were smoothly converted to the corresponding pyrazolidinones with excellent enantioselectivities ( $82-96 \%$ ee). The electronic

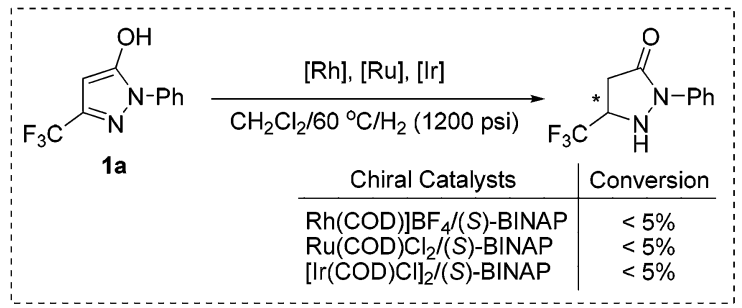

Scheme 2 Asymmetric hydrogenation of fluorinated pyrazol-5-ol 1a. a) Three tautomers of pyrazol-5-ol

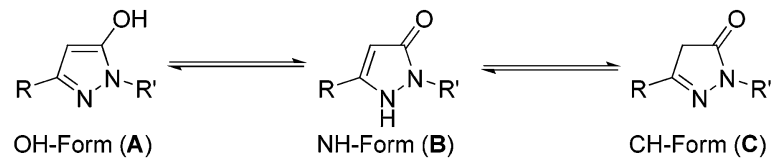

b) Asymmetric hydrogenation via capture of active tautomers

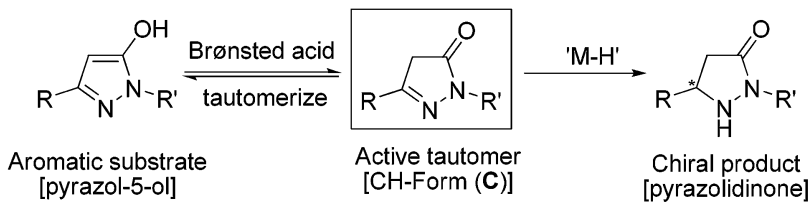

Scheme 3 The tautomeric forms of pyrazol-5-ols and the hydrogenation strategy.

properties of the substituents on the phenyl ring had little effect on the activity and enantioselectivity (entry $5 v s$. entries 6-8). However, the hydrogenation of 2-o-tolyl-substituted pyrazol-5-ol 1b gave a moderate $82 \%$ enantioselectivity and $67 \%$ yield (entry 2). When TangPhos L5, which was developed by Zhang's group in $2002,{ }^{28}$ was employed and the temperature was elevated to $100{ }^{\circ} \mathrm{C}$, the pyrazol-5-ol substrates $(\mathbf{1} \mathbf{i}-\mathbf{1} \mathbf{j})$ bearing a pentafluoroethyl substituent could also be hydrogenated with excellent enantioselectivities and yields (entries 9 and 10).

For the sake of further estimating the application possibility, a range of 4-substituted 3-(trifluoromethyl)- $1 H$-pyrazol-5-ols (3a-3g) were also investigated (Table 3). The substrates with an alkyl-substituent at the 4-position could be hydrogenated

Table 1 Optimization of the asymmetric hydrogenation of pyrazol-5ol $1 a^{a}$

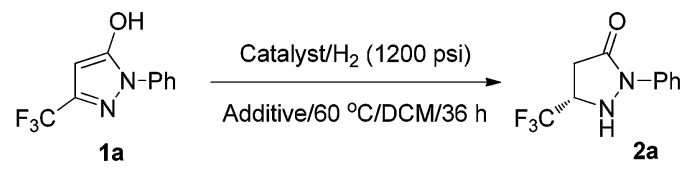

\begin{tabular}{|c|c|c|c|c|}
\hline Entry & Catalyst & Additive & Yield $(\%)^{b}$ & $\operatorname{Ee}(\%)^{c}$ \\
\hline 1 & $\mathrm{Pd}\left(\mathrm{OCOCF}_{3}\right)_{2}+\mathbf{L 1}$ & TFA & 54 & 91 \\
\hline $2^{d}$ & $\operatorname{Pd}\left(\mathrm{OCOCF}_{3}\right)_{2}+\mathbf{L 1}$ & TFA & 52 & 90 \\
\hline 3 & $\operatorname{Pd}\left(\mathrm{OCOCF}_{3}\right)_{2}+\mathbf{L 1}$ & L-CSA & 46 & 90 \\
\hline 4 & $\mathrm{Pd}\left(\mathrm{OCOCF}_{3}\right)_{2}+\mathbf{L 1}$ & D-CSA & 39 & 90 \\
\hline 5 & $\operatorname{Pd}\left(\mathrm{OCOCF}_{3}\right)_{2}+\mathbf{L 1}$ & $\mathrm{TsOH} \cdot \mathrm{H}_{2} \mathrm{O}$ & 32 & 90 \\
\hline 6 & $\operatorname{Pd}\left(\mathrm{OCOCF}_{3}\right)_{2}+\mathbf{L} 2$ & TFA & 81 & 96 \\
\hline 7 & $\mathrm{Pd}\left(\mathrm{OCOCF}_{3}\right)_{2}+\mathbf{L} 3$ & TFA & 46 & 93 \\
\hline 8 & $\operatorname{Pd}\left(\mathrm{OCOCF}_{3}\right)_{2}+\mathbf{L 4}$ & TFA & 29 & 90 \\
\hline 9 & $\operatorname{Pd}\left(\mathrm{OCOCF}_{3}\right)_{2}+\mathbf{L 5}$ & TFA & 20 & 97 \\
\hline $10^{e}$ & $\mathrm{Pd}\left(\mathrm{OCOCF}_{3}\right)_{2}+\mathbf{L} 2$ & TFA & 94 & 96 \\
\hline
\end{tabular}

${ }^{a}$ Reaction conditions: $\mathrm{Pd}\left(\mathrm{OCOCF}_{3}\right)_{2}(2 \mathrm{~mol} \%)$, ligand $(2.1 \mathrm{~mol} \%), \mathbf{1 a}$ $(0.3 \mathrm{mmol})$, additive $(0.3 \mathrm{mmol}), \mathrm{H}_{2}(1200 \mathrm{psi}), \mathrm{DCM}(2 \mathrm{~mL}), 60^{\circ} \mathrm{C}, 36$ h. ${ }^{b}$ Isolated yields. ${ }^{c}$ Determined by HPLC. ${ }^{d}$ Using TFE as solvent. ${ }^{e} 48 \mathrm{~h}$. 
Table 2 Pd-catalyzed asymmetric hydrogenation of pyrazol-5-ols $1^{a}$

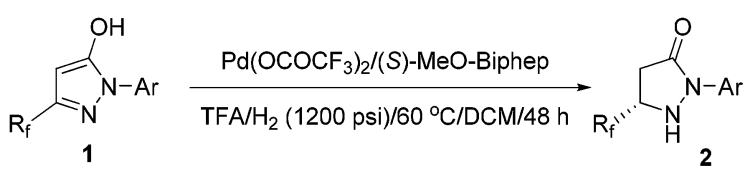

\begin{tabular}{lllll}
\hline Entry & $R_{\mathrm{F}}$ & $\mathrm{Ar}$ & ${\text { Yield }(\%)^{b}}^{b}$ & Ee $(\%)^{c}$ \\
\hline 1 & $\mathrm{CF}_{3}$ & $\mathrm{C}_{6} \mathrm{H}_{5}$ & $94(\mathbf{2 a})$ & $96(\mathrm{~S})$ \\
$2^{d}$ & $\mathrm{CF}_{3}$ & $2-\mathrm{MeC}_{6} \mathrm{H}_{4}$ & $67(\mathbf{2 b})$ & $82(+)$ \\
3 & $\mathrm{CF}_{3}$ & $3-\mathrm{MeC}_{6} \mathrm{H}_{4}$ & $93(\mathbf{2 c})$ & $95(+)$ \\
4 & $\mathrm{CF}_{3}$ & $4-\mathrm{MeC}_{6} \mathrm{H}_{4}$ & $93(\mathbf{2 d})$ & $96(+)$ \\
5 & $\mathrm{CF}_{3}$ & $4-\mathrm{MeOC}_{6} \mathrm{H}_{4}$ & $94(\mathbf{2 e})$ & $95(+)$ \\
6 & $\mathrm{CF}_{3}$ & $3-\mathrm{ClC}_{6} \mathrm{H}_{4}$ & $89(\mathbf{2 f})$ & $95(+)$ \\
7 & $\mathrm{CF}_{3}$ & $3,4-\mathrm{Cl}_{2} \mathrm{C}_{6} \mathrm{H}_{3}$ & $90(2 \mathbf{g})$ & $93(+)$ \\
8 & $\mathrm{CF}_{3}$ & $4-\mathrm{FC}_{6} \mathrm{H}_{4}$ & $93(\mathbf{2 h})$ & $94(+)$ \\
$9^{e}$ & $\mathrm{C}_{2} \mathrm{~F}_{5}$ & $\mathrm{C}_{6} \mathrm{H}_{5}$ & $95(2 \mathbf{i})$ & $94(-)$ \\
$10^{e}$ & $\mathrm{C}_{2} \mathrm{~F}_{5}$ & $4-\mathrm{MeC}_{6} \mathrm{H}_{4}$ & $92(2 \mathbf{j})$ & $95(-)$
\end{tabular}

${ }^{a} \mathrm{Pd}\left(\mathrm{OCOCF}_{3}\right)_{2}$ (2 mol\%), (S)-MeO-Biphep (2.1 mol\%), 1 (0.3 mmol), $\mathrm{H}_{2}$ (1200 psi), TFA ( $0.3 \mathrm{mmol}), \mathrm{DCM}(2 \mathrm{~mL}), 60{ }^{\circ} \mathrm{C}, 48 \mathrm{~h} .{ }^{b}$ Isolated yields. ${ }^{c}$ Determined by HPLC. ${ }^{d} \mathrm{Pd}\left(\mathrm{OCOCF}_{3}\right)_{2}(4 \mathrm{~mol} \%),(S)$-MeO-Biphep $(4.2$ $\mathrm{mol} \%), \mathbf{b}(0.2 \mathrm{mmol}), \mathrm{H}_{2}$ (1200 psi), TFA (0.2 mmol), DCM ( $\left.2 \mathrm{~mL}\right), 60$ ${ }^{\circ} \mathrm{C}, 48 \mathrm{~h} .{ }^{e} \mathrm{Pd}\left(\mathrm{OCOCF}_{3}\right)_{2}$ (4 mol\%), $\left(S, S^{\prime}, R, R^{\prime}\right)$-TangPhos $(5.2 \mathrm{~mol} \%), 1$ $(0.2 \mathrm{mmol}), \mathrm{H}_{2}(1200 \mathrm{psi}), \mathrm{L}-\mathrm{CSA}(0.2 \mathrm{mmol})$, TFE $(2 \mathrm{~mL}), 100^{\circ} \mathrm{C}, 48 \mathrm{~h}$.

Table 3 Pd-catalyzed asymmetric hydrogenation of pyrazol-5-ols $3^{a}$

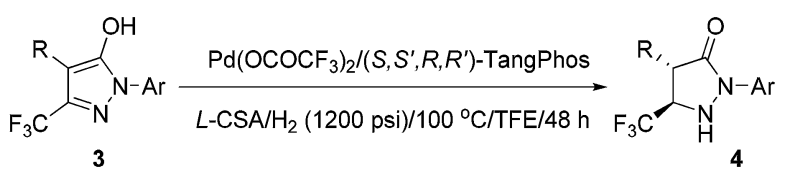

\begin{tabular}{lllll}
\hline Entry & $\mathrm{R}$ & $\mathrm{Ar}$ & ${\text { Yield }(\%)^{b}}^{b}$ & $\mathrm{Ee}(\%)^{c}$ \\
\hline 1 & $\mathrm{Me}$ & $\mathrm{C}_{6} \mathrm{H}_{5}$ & $92(\mathbf{4 a})$ & $89(-)$ \\
2 & $\mathrm{Me}$ & $4-\mathrm{MeC}_{6} \mathrm{H}_{4}$ & $97(\mathbf{4 b})$ & $88(+)$ \\
3 & $\mathrm{Et}$ & $\mathrm{C}_{6} \mathrm{H}_{5}$ & $93(\mathbf{4 c})$ & $94(+)$ \\
4 & $\mathrm{Et}$ & $4-\mathrm{MeC}_{6} \mathrm{H}_{4}$ & $92(\mathbf{4 d})$ & $93(+)$ \\
5 & $\mathrm{Et}$ & $3-\mathrm{MeC}_{6} \mathrm{H}_{4}$ & $90(\mathbf{4 e})$ & $92(+)$ \\
6 & ${ }^{n} \mathrm{Pr}$ & $\mathrm{C}_{6} \mathrm{H}_{5}$ & $95(\mathbf{4 f})$ & $93(+)$ \\
7 & $\mathrm{Bn}$ & $\mathrm{C}_{6} \mathrm{H}_{5}$ & $94(\mathbf{4 g})$ & $95(4 S, 5 R)$
\end{tabular}

${ }^{a} \mathrm{Pd}\left(\mathrm{OCOCF}_{3}\right)_{2}(4 \mathrm{~mol} \%),\left(S, S^{\prime}, R, R^{\prime}\right)$-TangPhos (5.2 mol\%), 3 (0.2 mmol), $\mathrm{H}_{2}(1200 \mathrm{psi}), \mathrm{L}-\mathrm{CSA}(0.2 \mathrm{mmol}), \mathrm{TFE}(2 \mathrm{~mL}), 100^{\circ} \mathrm{C}, 48 \mathrm{~h}$. In all cases $\mathrm{dr}$ $>20: 1 .{ }^{b}$ Isolated yields. ${ }^{c}$ Determined by HPLC.

smoothly, providing the corresponding the 2,4,5-trisubstituted pyrazolidinone derivatives with high enantioselectivity and diastereoselectivity. The high diastereoselectivity probably results from the thermodynamic stability of the trans products under these harsh acidic conditions. Substrates bearing long alkyl or bulky substituents at the C4 position gave slightly higher enantioselectivities (entry 1 vs. entries 3,6,7).

The absolute configurations of the hydrogenation products $\mathbf{2 a}$ and $\mathbf{4} \mathbf{g}$ were determined by X-ray diffraction analysis by recrystallization from the solvent mixture dichloromethane- $n$ hexane. ${ }^{29}$ The configurations of the other chiral products were assigned by analogy.

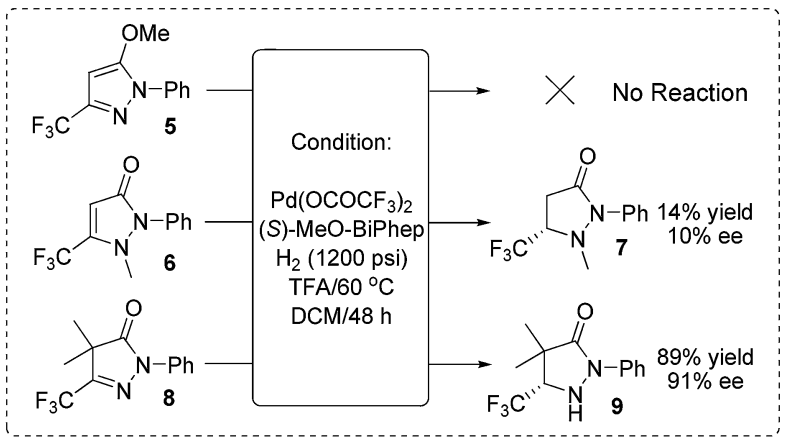

Scheme 4 Reactions of the mechanistic investigation. All reactions were carried out under the conditions of $\mathrm{Pd}\left(\mathrm{OCOCF}_{3}\right)_{2}$ (4 mol\%), (S)MeO-Biphep (5.2 mol\%), substrate $(0.2 \mathrm{mmol}), \mathrm{H}_{2}$ (1200 psi), TFA (0.2 $\mathrm{mmol}), \mathrm{DCM}(2 \mathrm{~mL}), 60^{\circ} \mathrm{C}, 48 \mathrm{~h}$.

In order to verify our hypothesis that the hydrogenation was carried out via capture of the active tautomer, we synthesized three compounds (form A type 5, form $\mathbf{B}$ type $\mathbf{6}$ and form $\mathbf{C}$ type 8) and subject them to identical hydrogenation reactions (Scheme 4). As expected, no reaction was observed for the substrate 5; for substrate 6, a low $10 \%$ ee and $14 \%$ yield were obtained; the $\mathrm{CH}$-form substrate 8 gave an excellent $91 \%$ ee with $89 \%$ yield. Based on the experimental results and stereochemistry of the products, we proposed that the reaction experienced the process of Brønsted acid promoted tautomerization to form $\mathbf{C H}$-form tautomer $\mathbf{C}$, followed by $\mathrm{Pd}$-catalyzed asymmetric hydrogenation of the active tautomer $\mathbf{C}$ to give the optically active pyrazolidinones. This preliminary result demonstrated the practicability of our strategy of asymmetric hydrogenation of the inseparable active isomers to realize hydrogenation of the intractable isomerisable substrates.

\section{Conclusions}

An efficient palladium-catalyzed asymmetric hydrogenation of fluorinated aromatic pyrazol-5-ols has been developed via capture of the active tautomers. A wide variety of 2,5-disubstituted and 2,4,5-trisubstituted pyrazolidinone derivatives have been synthesized with up to $96 \%$ and $95 \%$ ee, respectively. The hydrogenation pathway includes Brønsted acid promoted tautomerization of the pyrazol-5-ols and palladium-catalyzed asymmetric hydrogenation of the active tautomer. This study provides some enlightenment of the application of asymmetric hydrogenation and useful information for the design of new reactions. Further study on applying this novel strategy to other aromatic compounds and exploration of the applications of the chiral pyrazolidinones are in progress in our laboratory.

\section{Acknowledgements}

Financial support from the National Natural Science Foundation of China (21372220 and 21125208) is acknowledged. 


\section{Notes and references}

1 (a) L. N. Jungheim and S. K. Sigmund, J. Org. Chem., 1987, 52, 4007; (b) J. M. Indelicato and C. E. Pasini, J. Med. Chem., 1988, 31, 1227; (c) R. E. Holmes and D. A. Neel, Tetrahedron Lett., 1990, 31, 5567; (d) R. M. Claramunt and J. Elguero, Org. Prep. Proced. Int., 1991, 23, 273; (e) E. Couloigner, D. Cartier and R. Labia, Bioorg. Med. Chem. Lett., 1999, 9, 2205; (f) W. Chen, X. H. Yuan, R. Li, W. Du, Y. Wu, L. S. Ding and Y. C. Chen, Adv. Synth. Catal., 2006, 348, 1818; (g) L. Pezdirc, U. Groselj, A. Meden, B. Stanovnik and J. Svete, Tetrahedron Lett., 2007, 48, 5205; (h) L. Pezdirc, B. Stanovnik and J. Svete, Aust. J. Chem., 2009, 62, 1661.

2 C. M. R. Low, J. W. Black, H. B. Broughton, I. M. Buck, J. M. R. Davies, D. J. Dunstone, R. A. D. Hull, S. B. Kalindjian, I. M. McDonald, M. J. Pether, N. P. Shankley and K. I. M. Steel, J. Med. Chem., 2000, 43, 3505.

3 (a) E. Gould, T. Lebl, A. M. Z. Slawin, M. Reid and A. D. Smith, Tetrahedron, 2010, 66, 8992; (b) G. Ma, J. Deng and M. P. Sibi, Angew. Chem., Int. Ed., 2014, 53, 11818.

4 (a) J.-A. Ma and D. Cahard, Chem. Rev., 2004, 104, 6119; (b) K. Müller, C. Faeh and F. Diederich, Science, 2007, 317, 1881; (c) S. Purser, P. R. Moore, S. Swallow and V. Gouverneur, Chem. Soc. Rev., 2008, 37, 320; (d) J.-A. Ma and D. Cahard, Chem. Rev., 2008, 108, PR1; (e) D. Cahard, $\mathrm{X}$. Xu, S. Couve-Bonnaire and X. Pannecoucke, Chem. Soc. Rev., 2010, 39, 558; (f) Y. Zheng and J.-A. Ma, Adv. Synth. Catal., 2010, 352, 2745; (g) T. Furuya, A. S. Kamlet and T. Ritter, Nature, 2011, 473, 470; $(h)$ J. Nie, H.-C. Guo, D. Cahard and J.-A. Ma, Chem. Rev., 2011, 111, 455; (i) H.-R. He, Y.-Y. Huang and F. Verpoort, Acta Chim. Sin., 2013, 71, 700.

5 C. Seki, M. Hirama, T. Sato, S. Takeda, Y. Kohari, K. Ishigaki, M. Ohuchi, K. Yokoi, H. Nakano, K. Uwai, N. Takano, K. Umemura and H. Matsuyama, Heterocycles, 2012, 85, 1045.

6 M. Wang, Z. Huang, J. Xu and Y.-R. Chi, J. Am. Chem. Soc., 2014, 136, 1214.

7 For recent reviews on asymmetric hydrogenation of heteroaromatic compounds, see: (a) F. Glorius, Org. Biomol. Chem., 2005, 3, 4171; (b) S.-M. Lu, X.-W. Han and Y.-G. Zhou, Chin. J. Org. Chem., 2005, 25, 634; (c) Y.-G. Zhou, Acc. Chem. Res., 2007, 40, 1357; (d) D.-S. Wang, Q.-A. Chen, S.-M. Lu and Y.-G. Zhou, Chem. Rev., 2012, 112, 2557; (e) Y.-M. He, F.-T. Song and Q.-H. Fan, Top. Curr. Chem., 2014, 343, 145; $(f)$ Z.-S. Ye, L. Shi and Y.-G. Zhou, Synlett, 2014, 25, 928; (g) J. Xie and Q. Zhou, Acta Chim. Sin., 2012, 70, 1427.

8 For representative reports on asymmetric hydrogenation of quinolines, see: (a) W.-B. Wang, S.-M. Lu, P.-Y. Yang, X.-W. Han and Y.-G. Zhou, J. Am. Chem. Soc., 2003, 125, 10536; (b) M. Rueping, A. P. Antonchick and T. Theissmann, Angew. Chem., Int. Ed., 2006, 45, 3683; (c) Q.-S. Guo, D.-M. Du and J. Xu, Angew. Chem., Int. Ed., 2008,
47, 759; (d) H. Zhou, Z. Li, Z. Wang, T. Wang, L. Xu, Y. He, Q.-H. Fan, J. Pan, L. Gu and A. S. C. Chan, Angew. Chem., Int. Ed., 2008, 47, 8464; (e) C. Wang, C. Li, X. Wu, A. Pettman and J. Xiao, Angew. Chem., Int. Ed., 2009, 48, 6524; $(f)$ T. Wang, L.-G. Zhuo, Z. Li, F. Chen, Z. Ding, Y. He, Q.-H. Fan, J. Xiang, Z.-X. Yu and A. S. C. Chan, J. Am. Chem. Soc., 2011, 133, 9878; (g) Q.-A. Chen, K. Gao, Y. Duan, Z.-S. Ye, L. Shi, Y. Yang and Y.-G. Zhou, J. Am. Chem. Soc., 2012, 134, 2442; (h) T. Wang, F. Chen, J. Qin, Y.-M. He and Q.-H. Fan, Angew. Chem., Int. Ed., 2013, 52, 7172 .

9 For recent works on asymmetric reduction of isoquinolines, see: (a) S.-M. Lu, Y.-Q. Wang, X.-W. Han and Y.-G. Zhou, Angew. Chem., Int. Ed., 2006, 45, 2260; (b) L. Shi, Z.-S. Ye, L.-L. Cao, R.-N. Guo, Y. Hu and Y.-G. Zhou, Angew. Chem., Int. Ed., 2012, 51, 8286; (c) A. Iimuro, K. Yamaji, S. Kandula, T. Nagano, Y. Kita and K. Mashima, Angew. Chem., Int. Ed., 2013, 52, 2046; (d) Z.-S. Ye, R.-N. Guo, X.-F. Cai, M.-W. Chen, L. Shi and Y.-G. Zhou, Angew. Chem., Int. Ed., 2013, 52, 3685.

10 For representative reports on asymmetric hydrogenation of quinoxalines, see: (a) C. Bianchini, P. Barbaro, G. Scapacci, E. Farnetti and M. Graziani, Organometallics, 1998, 17, 3308; (b) W. Tang, L. Xu, Q.-H. Fan, J. Wang, B. Fan, Z. Zhou, K.-H. Lam and A. S. C. Chan, Angew. Chem., Int. Ed., 2009, 48, 9135; (c) M. Rueping, F. Tato and F. R. Schoepke, Chem.-Eur. J., 2010, 16, 2688; (d) Q.-A. Chen, D.-S. Wang, Y.-G. Zhou, Y. Duan, H.-J. Fan, Y. Yang and Z. Zhang, J. Am. Chem. Soc., 2011, 133, 6126; (e) J. Qin, F. Chen, Z. Ding, Y.-M. He, L. Xu and Q.-H. Fan, Org. Lett., 2011, 13, 6568; (f) Z. Zhang and H. Du, Angew. Chem., Int. Ed., 2015, 54, 623.

11 For representative reports on asymmetric hydrogenation of pyridines, see: (a) M. Studer, C. Wedemeyer-Exl, F. Spindler and H.-U. Blaser, Monatsh. Chem., 2000, 131, 1335; (b) F. Glorius, N. Spielkamp, S. Holle, R. Goddard and C. W. Lehmann, Angew. Chem., Int. Ed., 2004, 43, 2850; (c) C. Y. Legault and A. B. Charette, J. Am. Chem. Soc., 2005, 127, 8966; (d) M. Rueping and A. P. Antonchick, Angew. Chem., Int. Ed., 2007, 46, 4562; (e) X.-B. Wang, W. Zeng and Y.-G. Zhou, Tetrahedron Lett., 2008, 49, 4922; ( $f$ ) W.-J. Tang, J. Tan, L.-J. Xu, K.-H. Lam, Q.-H. Fan and A. S. C. Chan, Adv. Synth. Catal., 2010, 352, 1055; (g) Z.-S. Ye, M.-W. Chen, Q.-A. Chen, L. Shi, Y. Duan and Y.-G. Zhou, Angew. Chem., Int. Ed., 2012, 51, 10181; (h) Y. Liu and H. Du, J. Am. Chem. Soc., 2013, 135, 12968; (i) M. Chang, Y. Huang, S. Liu, Y. Chen, S. W. Krska, I. W. Davies and X. Zhang, Angew. Chem., Int. Ed., 2014, 53, 12761; (j) Y. Kita, A. Iimuro, S. Hida and K. Mashima, Chem. Lett., 2014, 43, 284.

12 For representative reports on asymmetric hydrogenation of indoles, see: (a) R. Kuwano, K. Sato, T. Kurokawa, D. Karube and Y. Ito, J. Am. Chem. Soc., 2000, 122, 7614; (b) A. Baeza and A. Pfaltz, Chen.-Eur. J., 2010, 16, 2036; (c) D.-S. Wang, Q.-A. Chen, W. Li, C.-B. Yu, Y.-G. Zhou and X. Zhang, J. Am. Chem. Soc., 2010, 132, 8909; (d) Y.-C. Xiao, C. Wang, Y. Yao, J. Sun and Y.-C. Chen, Angew. Chem., Int. 
Ed., 2011, 50, 10661; (e) Y. Duan, L. Li, M.-W. Chen, C.-B. Yu, H.-J. Fan and Y.-G. Zhou, J. Am. Chem. Soc., 2014, 136, 7688. 13 For reports on asymmetric hydrogenation of pyrroles, see:

(a) R. Kuwano, M. Kashiwabara, M. Ohsumi and H. Kusano, J. Am. Chem. Soc., 2008, 130, 808; (b) D.-S. Wang, Z.-S. Ye, Q.-A. Chen, Y.-G. Zhou, C.-B. Yu, H.-J. Fan and Y. Duan, J. Am. Chem. Soc., 2011, 133, 8866.

14 For reports on asymmetric hydrogenation of (benzo)furans, see: (a) S. Kaiser, S. P. Smidt and A. Pfaltz, Angew. Chem., Int. Ed., 2006, 45, 5194; (b) N. Ortega, S. Urban, B. Beiring and F. Glorius, Angew. Chem., Int. Ed., 2012, 51, 1710; (c) J. Wysocki, N. Ortega and F. Glorius, Angew. Chem., Int. Ed., 2014, 53, 8751.

15 For a report on asymmetric hydrogenation of (benzo) thiophenes, see: S. Urban, B. Beiring, N. Ortega, D. Paul and F. Glorius, J. Am. Chem. Soc., 2012, 134, 15241.

16 For a report on asymmetric hydrogenation of imidazoles and oxazoles, see: R. Kuwano, N. Kameyama and R. Ikeda, J. Am. Chem. Soc., 2011, 133, 7312.

17 N. Ortega, D. D. Tang, S. Urban, D. Zhao and F. Glorius, Angew. Chem., Int. Ed., 2013, 52, 9500.

18 R. Kuwano, Y. Hashiguchi, R. Ikeda and K. Ishizuka, Angew. Chem., Int. Ed., 2015, 54, 2393.

19 J. Zhang, F. Chen, Y.-M. He and Q.-H. Fan, Angew. Chem., Int. Ed., 2015, 54, 4622 .
20 For a report on asymmetric hydrogenation of benzisoxazoles with the cleavage of the bond between the heteroatoms, see: R. Ikeda and R. Kuwano, Molecules, 2012, 17, 6901.

21 J. Zhang, S. Yang, K. Zhang, J. Chen, H. Deng, M. Shao, H. Zhang and W. Cao, Tetrahedron, 2012, 9, 2121.

22 W. Holzer, B. Plagens and K. Lorenz, Heterocycles, 1997, 45, 309.

23 S. Bieringer and W. Holzer, Heterocycles, 2006, 68, 1825.

24 ESI. $\dagger$

25 (a) H. Laatsch, Liebigs Ann. Chem., 1980, 140; (b) E. P. Kündig, A. Enriquez-Garcia, T. Lomberget and G. Bernardinelli, Angew. Chem., Int. Ed., 2006, 45, 98; (c) E. P. Kündig and A. Enriquez-Garcia, Beilstein J. Org. Chem., 2008, 4, 37.

26 (a) X.-Y. Zhou, M. Bao and Y.-G. Zhou, Adv. Synth. Catal., 2011, 353, 84; (b) D.-S. Wang, J. Tang, Y.-G. Zhou, M.-W. Chen, C.-B. Yu, Y. Duan and G.-F. Jiang, Chem. Sci., 2011, 2, 803; (c) X.-Y. Zhou, D.-S. Wang, M. Bao and Y.-G. Zhou, Tetrahedron Lett., 2011, 52, 2826; (d) C.-B. Yu, K. Gao, Q.-A. Chen, M. W. Chen and Y.-G. Zhou, Tetrahedron Lett., 2012, 53, 2560; (e) Y. Duan, M.-W. Chen, Q.-A. Chen, C.-B. Yu and Y.-G. Zhou, Org. Biomol. Chem., 2012, 10, 1235.

27 Y. Duan, L. Li, M.-W. Chen, C.-B. Yu, H.-J. Fan and Y.-G. Zhou, J. Am. Chem. Soc., 2014, 136, 7688.

28 W. Tang and X. Zhang, Angew. Chem., Int. Ed., 2002, 41, 1612. 29 ESI. $\dagger$ 